\title{
KLASIFIKASI TEKNOLOGI DALAM JARINGAN UNTUK MENDUKUNG PROSES PEMBELAJARAN JARAK JAUH DI ERA MERDEKA BELAJAR
}

\author{
Ni Made Dian Widiastuti ${ }^{1}$, I Putu Arya Dharmaadi ${ }^{2)}$ \\ 1 Program Studi Pendidikan Seni Pertunjukan, Institut Seni Indonesia Denpasar \\ 2 Program Studi Teknologi Informasi, Fakultas Teknik, Universitas Udayana \\ Email: dianwidiastuti@isi-dps.ac.id, aryadharmaadi@unud.ac.id
}

\begin{abstract}
ABSTRAK
Teknologi pada pendidikan saat ini memiliki peranan yang sangat penting, namun kenyataannya tidak semua guru mampu mengaplikasikan atau menggunakan teknologi dalam pembelajaran, karena sulitnya pengoperasian dari teknologi dan bingung dalam memilih jenis teknologi yang sesuai dengan kondisi kelas. Dengan demikian, pada penelitian ini akan dikaji beberapa jenis teknologi informasi dalam jaringan yang sering dan mudah digunakan dalam pembelajaran saat ini. Metode penelitian dan penulisan artikel ini menggunakan pendekatan kajian literatur dan metode komparatif. Sumber data diperoleh dari artikel-artikel dari portal berita online yang terbit di tahun 2020, buku, dan artikel ilmiah, yang berkaitan dengan teknologi pembelajaran dalam jaringan dan dipublikasikan selama 5 tahun terakhir. Berdasarkan karakteristiknya, hasil identifikasi teknologi informasi berbasis jaringan terdiri dari teknologi pemberian materi, teknologi evaluasi, dan platform khusus. Melalui hasil pengelompokan teknologi pembelajaran ini, guru dapat memahami dan memilih teknologi pembelajaran yang sesuai dengan kondisi dan materi ajar.
\end{abstract}

Kata kunci: identifikasi, teknologi, pembelajaran, dalam jaringan

\begin{abstract}
Technology in education currently has a very important role, but in reality not all teachers are able to apply or use technology in learning, because of the difficulty of the operation and confusion in choosing the type of technology in accordance with the conditions of the class. Thus, this research will examine several types of online information technology that are often used in learning today. The research method and writing of this article uses literature review and comparative method. Sources of data were obtained from articles from online news portals, which were published in 2020, books and scientific articles, which relating to learning technology in networks and published over the past 5 years. Based on its characteristics, the results of the identification of online information technology consists of material delivery technology, evaluation technology, and special platform. Through the results of this grouping of learning technologies, teachers can understand and choose learning technologies that are in accordance with the conditions and teaching material.
\end{abstract}

Keywords : identification, technology, education, online

\section{PENDAHULUAN}

Merdeka belajar yang menjadi bahan perbincangan saat ini merupakan kebijakan yang dirancang oleh Menteri Pendidikan Nadiem Makariem, dimana nuansa kegiatan belajar yang dahulunya hanya didominasi di kelas, kini dapat dilakukan di luar kelas, dan tidak mengandalkan nilai semata. Kebijakan yang digaungkan ini sebagai upaya untuk meningkatkan kualitas SDM di Indonesia. Hal ini didasarkan pada data yang dikutip dari Kompas.com, yaitu Bappenas menyampaikan bahwa sumber daya manusia di Indonesia berada pada posisi yang masih tertinggal, dibandingkan negara lain, seperti Vietnam [1]. Tertinggalnya kualitas sumber daya manusia di Indonesia dipengaruhi oleh salah satu faktor yaitu sistem pendidikannya, seperti yang diketahui bahwa pendidikan di Indonesia pada umumnya berlangsung secara klasik dan monoton, yaitu kegiatan belajar yang berlangsung di dalam kelas dengan dipandu oleh seorang guru dalam penyampaian materi. Kegiatan seperti itu menjadikan suasana belajar menegangkan dan 
membosankan. Kreativitas siswa dan wawasan menjadi terbatas. Hal ini yang perlu dipikirkan dalam upaya meningkatkan kualitas SDM agar kegiatan belajar dapat berlangsung dengan suasana yang lebih aktif, senang, menyenangkan, fleksibel, dan dapat dilakukan dimana saja tanpa ada batas ruang ataupun waktu. Hal lain yang mempengaruhi kualitas sumber daya manusia di Indonesia adalah pola pikir yang dibentuk dalam kegiatan belajar hanya untuk memperoleh nilai semata, sehingga aspek sikap dan mental siswa tidak terbentuk secara maksimal.

Dalam menanggapi kebijakan merdeka belajar harus diimbangi dengan kompetensi yang dimiliki oleh seorang guru. Sebagai seorang guru harus menguasai empat kompetensi dasar yaitu kompetensi pedagogi, kompetensi kepribadian, kompetensi sosial, dan kompetensi profesional. Guru adalah tonggak awal yang membentuk generasi menjadi manusia yang lebih baik. Tugas guru adalah menumbuhkan keingintahuan anak didik dan mengarahkannya dengan cara yang paling mereka minati. Idealnya seorang guru tidak hanya harus pintar atau ahli di bidang ilmu yang dimiliki saja, melainkan guru harus mampu menempatkan diri sebagai sumber perubahan dan penggerak. Dengan posisi seorang guru sebagai penggerak tentunya dalam kegiatan belajar, guru harus mampu menciptakan suasana belajar yang menyenangkan, inovatif, dan menantang. Kreativitas guru dalam mengelola kelas sangat dibutuhkan untuk mencapai tujuan dari merdeka belajar.

Saat ini teknologi berkembang dengan pesat dan kehadirannya sangat membantu pekerjaan manusia, termasuk dalam bidang pendidikan. Guru dengan tuntutannya harus mampu berinovasi dapat memanfaatkan teknologi untuk mencapai tujuan pembelajaran yang diinginkan dan kegiatan belajar dapat dilakukan dimana saja tanpa terbatas oleh ruang dan waktu. Namun kenyataannya tidak semua guru mampu mengaplikasikan atau menggunakan teknologi dalam pembelajaran jarak jauh, karena sulitnya pengoperasian dari teknologi tersebut. Kurang paham mengenai teknologi, cenderung menimbulkan rasa enggan dan bingung dalam memilih jenis teknologi yang sesuai dengan kondisi kelas. berikut.

Dengan demikian, rumusan masalah yang akan diangkat pada penelitian ini adalah sebagai

- Bagaimana memudahkan guru-guru dalam memilih teknologi yang sesuai dengan karakteristik pembelajarannya?

Berdasarkan rumusan masalah di atas, penelitian ini memiliki tujuan yang akan dipaparkan sebagai berikut.

- Mempermudah guru-guru dalam memilih teknologi yang sesuai dengan cara mengklasifikasikan aplikasi-aplikasi berbasis jaringan menjadi beberapa kelompok berdasarkan indikator tertentu.

Melalui hasil kajian penelitan ini, diharapkan pembaca bisa memahami dan memilih teknologi pembelajaran sesuai dengan model pembelajaran yang diinginkan.

\section{METODE}

Untuk menjawab rumusan masalah yang telah diuraikan pada bab 1, penelitian ini merumuskan 4 tahapan penelitian yang akan dikerjakan. Tahapan tersebut adalah sebagai berikut.

1. Mengidentifikasi aplikasi yang bisa digunakan oleh guru-guru untuk melaksanakan pembelajaran jarak jauh.

2. Mengeksplorasi faktor-faktor kunci dalam pembelajaran jarak jauh yang perlu dipertimbangkan.

3. Mengklasifikasikan aplikasi-aplikasi tersebut menjadi beberapa kelompok berdasarkan faktor kunci sehingga mempermudah guru-guru memilih teknologi yang sesuai.

4. Merumuskan keunggulan dan kelemahan dari setiap kelompok aplikasi.

Pada penelitian ini, diterapkan 2 metode penelitian, yaitu metode kajian literatur dan metode penelitian komparatif. Metode kajian literature digunakan untuk mengerjakan tahapan penelitian nomor (1) dan (2), sedangkan metode komparatif digunakan untuk mengerjakan tahapan penelitian nomor (3) dan (4).

\section{A. Kajian Literatur}

Penelitian dengan metode kajian literature, atau metode yang menggunakan pendekatan kepustakaan, adalah serangkaian penelitian yang berkenaan dengan metode pengumpulan data pustaka atau penelitian yang obyek penelitiannya digali melalui beragam informasi kepustakaan (buku, ensiklopedi, jurnal, koran, majalah dan dokumen) [2]. Data yang digunakan adalah data sekunder yaitu data yang diperoleh dari hasil penelitian terdahulu. Sumber data lainnya juga diperoleh dari artikel-artikel yang bersumber pada portal berita online, seperti Kompas.com, Detik.com, Jawapos.com, dan Tribunnews.com, yang terbit di tahun 2020, buku, dan artikel ilmiah, baik yang 
bereputasi nasional maupun internasional, yang berkaitan dengan teknologi pembelajaran dalam jaringan dan dipublikasikan selama 5 tahun terakhir. Kriteria pemilihan sumber didasarkan atas empat aspek mulai dari (1) Provenance (bukti), yakni aspek kredensial penulis dan dukungan bukti; (2) Objectivity (Objektifitas) berkaitan dengan untung ruginya ide perspektif dari penulis; (3) Persuasiviness (derajat keyakinan) yaitu golongan penulis; dan (4) Value kontribusi sumber terhadap penelitian [2].

Adapun sumber-sumber yang digunakan untuk memperoleh data mengenai jenis teknologi apa saja yang dapat digunakan dalam kegiatan pembelajaran saat ini, antara lain artikel yang ditulis oleh [3] dengan beberapa pertimbangan pemilihan, yaitu (1) relevansi artikel dengan masalah pada penelitian ini, (2) artikel tersebut berkelas nasional terakreditasi SINTA 2, sehingga tingkat keabsahannya dapat dipertanggungjawabkan. Artikel tersebut berisi tentang infrastruktur yang mendukung pembelajaran online secara gratis melalui berbagai ruang diskusi seperti Whatsapp, Google Classroom, dan Zenius. Artikel berikutnya yang mendukung penelitian bersumber dari [4]. Isi artikel tersebut mengenai aplikasi populer yang digunakan guru dan siswa dalam proses pembelajaran daring. Sumber lainnya adalah beberapa artikel portal online yaitu Kompas.com yang berjudul "5 Platform Untuk Belajar Bareng Teman Dari Rumah" yang membahas jenis platform dalam membantu kegiatan belajar daring menjadi lebih menyenangkan. Data berupa jenis teknologi dalam jaringan yang dapat digunakan pada kegiatan pembelajaran nantinya akan diidentifikasi, dikelompokkan berdasarkan kategori sesuai dengan karakteristik dan model interaksinya dengan menggunakan metode komparatif.

Teknik Pengumpulan data dalam penelitian ini menggunakan teknik dokumentasi karena sumber data berupa data tertulis. Langkah pengumpulan data menggunakan dokumentasi diuraikan sebagai berikut (1) membaca dan memahami isi sumber data; (2) mencatat hal-hal pokok yang berkaitan dengan penelitian; (3) mengolah data yang telah tercatat. Analisis yang digunakan adalah analasis deskriptif yaitu data dipaparkan secara sistematis agar dapat dipahami dengan baik.

\section{B. Metode Komparatif}

Metode komparatif merupakan metode yang bertujuan untuk membandingkan keberadaan suatu variabel atau lebih pada dua dengan waktu yang berbeda. Sifat dari metode komparatif ini yaitu data yang dikumpulkan setelah peristiwa yang dipermasalahkan terjadi [5]. Metode komparatif dapat juga diartikan sebagai suatu bentuk penelitian yang membandingkan antara variabel-variabel yang saling berhubungan dengan menentukan perbedaan dan persamaannya [6]. Adapun beberapa prosedur pada metode komparatif antara lain (1) penentuan masalah penelitian; (2) penentuan kategori; (3) menganalisa dan mengidentifikasi perbedaan dari setiap kategori dilihat dari aspek kelebihan dan kelemahannya.

Dengan demikian, pada penelitian ini, seluruh aplikasi yang terjawab dari rumusan masalah nomor 1 akan dibandingkan antara 1 aplikasi dengan aplikasi lainnya. Indikator yang dijadikan perbandingan aplikasi adalah indikator-indikator yang berhasil diidentifikasi berdasarkan rumusan masalah nomor 2. Aplikasi-aplikasi yang memiliki kemiripan akan dikelompokkan menjadi kategori yang sama. Dari kategori-kategori yang sudah terbentuk, akan diuji lagi kemiripannya dan perbedaannya berdasarkan indikator-indikator sebelumnya. Kategori yang memiliki kemiripan akan digabungkan lagi untuk membentuk kategori yang lebih besar. Begitu seterusnya hingga terbentuk satu kesatuan kategori besar, yang berperan sebagai root (akar) dengan ruang lingkup seluruh aplikasi. Setelah terbentuknya hasil pengelompokan, dengan menggunakan indikator-indikator yang sama, akan ditelaah kembali kelebihan dan kelemahan dari setiap kelompok aplikasi sehingga dapat melengkapi pemahaman pembaca tentang klasifikasi aplikasi pembelajaran jarak jauh.

\section{HASIL DAN PEMBAHASAN}

Dalam menunjang kegiatan belajar mengajar, seorang guru, dosen, atau pengajar membutuhkan media pembelajaran yang sesuai dengan karakteristik pengajaran. Media pembelajaran adalah seluruh alat peraga yang dirancang untuk menyampaikan materi atau pesanpesan pembelajaran dan membangun interaksi antara peserta didik dengan pengajar [7]. Mengingat semakin pesatnya perkembangan teknologi, maka media pembelajaran konvensional seperti kaset, DVD, atau papan tulis mulai ditinggalkan dan beralih ke media pembelajaran yang berbasis teknologi informasi dalam jaringan (online). Media pembelajaran jenis ini memungkinkan proses pembelajaran dapat dilakukan tanpa dibatasi ruang dan waktu sehingga terbentuklah model pembelajaran jarak jauh [8]. 
Berdasarkan hasil penelusuran pada portal berita online, buku, dan artikel ilmiah, penelitian ini telah berhasil mengidentifikasi beberapa aplikasi populer berbasis jaringan yang digunakan sebagai media pembelajaran jarak jauh. Adapun aplikasi populer tersebut akan dijabarkan pada tabel berikut.

Tabel 1. Daftar aplikasi berbasis jaringan untuk pembelajaran jarak jauh

\begin{tabular}{|c|c|c|c|c|}
\hline Nomor & Nama Aplikasi & Kegunaan & $\begin{array}{l}\text { Berjalan pada } \\
\text { Platform }\end{array}$ & Tarif penggunaan \\
\hline 1 & Zoom[9] & Online Meeting & $\begin{array}{l}\text { Web, Android, iOS, } \\
\text { Windows, MacOS }\end{array}$ & $\begin{array}{l}\text { Gratis } 40 \text { menit } \\
\text { pertama }\end{array}$ \\
\hline 2 & Webex [10] & Online Meeting & $\begin{array}{l}\text { Web, Android, iOS, } \\
\text { Windows, MacOS }\end{array}$ & Berbayar \\
\hline 3 & Google Meet [10] & Online Meeting & Web & Gratis \\
\hline 4 & Skype [11] & Online Meeting & $\begin{array}{l}\text { Web, Android, iOS, } \\
\text { Windows, MacOS }\end{array}$ & Gratis \\
\hline 5 & Whatsapp [12] & Berbagi pesan instan & $\begin{array}{l}\text { Web, Android, iOS, } \\
\text { Windows, MacOS }\end{array}$ & Gratis \\
\hline 6 & Telegram[11] & Berbagi pesan instan & $\begin{array}{l}\text { Web, Android, iOS, } \\
\text { Windows, MacOS }\end{array}$ & Gratis \\
\hline 7 & Line[11] & Berbagi pesan instan & $\begin{array}{l}\text { Android, iOS, } \\
\text { Windows, MacOS }\end{array}$ & Gratis \\
\hline 8 & $\begin{array}{l}\text { Apple } \\
\text { Podcast[13] }\end{array}$ & Berbagi podcast & iOS, MacOS & Gratis \\
\hline 9 & Castbox[13] & Berbagi podcast & $\begin{array}{l}\text { Web, Android, iOS, } \\
\text { Windows, MacOS }\end{array}$ & Gratis \\
\hline 10 & Youtube [12] & Berbagi video & $\begin{array}{l}\text { Web, Android, iOS, } \\
\text { Windows, MacOS }\end{array}$ & Gratis \\
\hline 11 & $\begin{array}{l}\text { Blogger Blogspot } \\
\text { [14] }\end{array}$ & $\begin{array}{l}\text { Berbagi tulisan dan } \\
\text { multimedia }\end{array}$ & Web & Gratis \\
\hline 12 & Wordpress [14] & $\begin{array}{l}\text { Berbagi tulisan dan } \\
\text { multimedia }\end{array}$ & Web & Gratis \\
\hline 13 & Moodle [15] & $\begin{array}{l}\text { Manajemen kelas, } \\
\text { materi, dan ujian }\end{array}$ & Web & Berbayar \\
\hline 14 & $\begin{array}{l}\text { Google } \\
\text { Classromm [9] }\end{array}$ & $\begin{array}{l}\text { Manajemen kelas } \\
\text { dan materi }\end{array}$ & $\begin{array}{l}\text { Web, Android, iOS, } \\
\text { Windows, MacOS }\end{array}$ & Gratis \\
\hline
\end{tabular}

Selanjutnya, berdasarkan hasil studi literatur pada referensi [16][13][17], didapatkan bahwa indikator-indikator yang perlu diperhatikan untuk efektifitas pembelajaran jarak jauh adalah sebagai berikut.

1.Model Interaksi

Pada proses pembelajaran dengan menggunakan teknologi jaringan, akan terjadi model interaksi antara guru dan siswa. Model interaksi yang umum dijumpai adalah model interaksi secara langsung (synchronous) dan tidak langsung (asynchronous) [18]. Model interaksi secara langsung memungkinkan guru dan siswa mendapatkan umpan balik pada saat itu juga dan hal sebaliknya terjadi pada model interaksi tidak langsung.

2.Bandwidth

Indikator selanjutnya yang perlu diperhatikan adalah bandwith. Bandwith merupakan banyaknya data dalam satuan bit atau byte yang melewati suatu kanal jaringan tertentu dalam satu detik. Semakin rendah bandwith yang dibutuhkan oleh aplikasi berarti semakin cepat pertukaran data yang terjadi [19]

3.Pindai cepat (skimming)

Dalam pembelajaran jarak jauh skimming dapat diartikan sebagai cara membaca dengan langsung mencari ide pokok utamanya tanpa membaca unsur pendukung lainnya [20].

Kemudian, dengan menggunakan metode komparasi, aplikasi-aplikasi yang dipaparkan pada tabel 1 akan diklasifikan sesuai dengan 3 indikator di atas. Hasil pengelompokkan aplikasi tersebut bisa dilihat pada gambar 1 di bawah ini. 


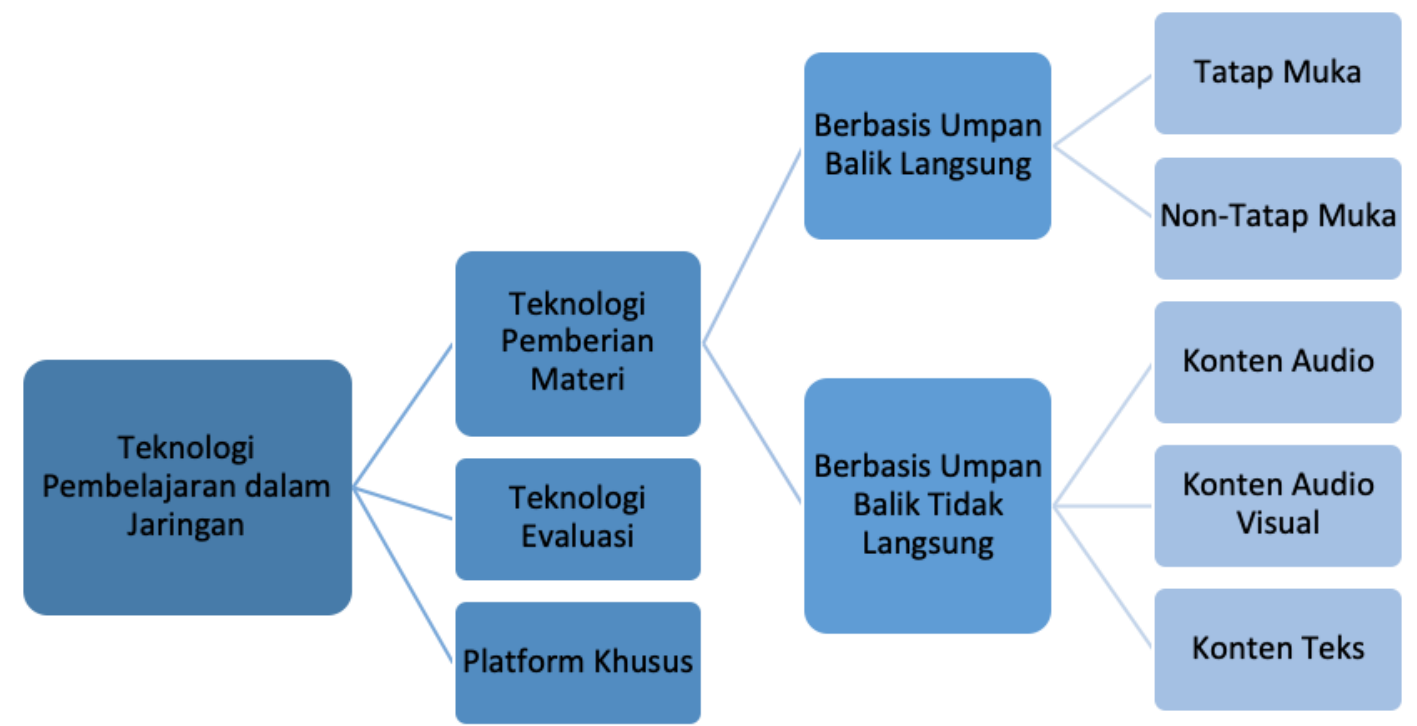

Gambar 1. Pengelompokkan teknologi informasi pembelajaran berdasarkan karakteristiknya

Secara garis besar, teknologi pembelajaran dalam jaringan bisa dibagi menjadi 3 jenis, yaitu teknologi pemberian materi, teknologi evaluasi, dan platform khusus.

\section{A. Teknologi Pemberian Materi}

Teknologi pemberian materi adalah jenis teknologi yang dimanfaatkan oleh penggunanya secara umum untuk memberikan informasi terkait sesuatu objek yang akan di bahas. Berdasarkan karakteristik peserta didik yang menerima materi, teknologi pemberian materi bisa digolongkan ke dalam dua jenis yaitu berbasis umpan balik langsung dan berbasis umpan balik tidak langsung. Berikut penjelasan mengenai kedua jenis teknologi tersebut.

\section{a) Berbasis Umpan Balik Langsung}

Teknologi berbasis umpan balik langsung adalah teknologi yang memungkinkan pemateri dapat berkomunikasi langsung dengan penerima materi. Umpan balik (respon) dari penerima materi dalam menggunakan teknologi ini dengan mudah didapatkan karena sifatnya yang realtime. Pada saat penyaji memberikan materi, sewaktu-waktu peserta yang mendengarkan dapat menyela untuk bertanya dan penyaji pun dapat memberikan penjelasan langsung terkait pertanyaan tersebut. Teknologi yang termasuk dalam basis umpan balik langsung terbagi menjadi 2 jenis, yaitu dalam bentuk tatap muka dan non-tatap muka.

\section{1) Tatap Muka}

Teknologi berbasis umpan balik langsung dalam bentuk tatap muka merupakan jenis teknologi yang memungkinkan penggunanya dapat berinteraksi dengan menampilkan wajah dan dapat memberikan respon secara langsung pada saat interaksi. Dengan tatap muka langsung antara pembicara dengan para peserta didik seakan-akan berada pada jarak yang sangat dekat. Selain itu, teknologi ini memungkinkan adanya share screen sehingga peserta didik bisa memperhatikan materi yang sedang dijelaskan. Teknologi tatap muka dapat digunakan sebagai penunjang kegiatan belajar pada peserta didik dari anak-anak sampai dengan dewasa. Untuk dapat memanfaatkan teknologi jenis ini dengan baik, para penggunanya diwajibkan memiliki sumber daya komputasi yang tinggi, seperti kecepatan jaringan internet (bandwidth) yang besar, kuota data internet yang besar, dan perangkat laptop atau smartphone yang handal.

Beberapa contoh aplikasi yang tergolong teknologi bentuk tatap muka yaitu zoom meetings dan webex. Dua aplikasi ini awalnya sering digunakan untuk melakukan rapat jarak jauh pada perusahaan-perusahaan multinasional. Namun, karena adanya pandemi virus Covid-19 yang menyebabkan seluruh kegiatan belajar mengajar di sekolah dan kampus harus dilakukan dari rumah masing-masing, aplikasi zoom meeting dan webex menjadi populer untuk melaksanaan pendidikan jarak jauh [21].

Zoom Meetings merupakan aplikasi yang memberikan layanan meeting online dengan konsep screen sharing yang memungkinkan penggunanya bertatap muka dengan maksimal 10.000 orang partisipan [22]. Zoom memiliki kelebihan yang tak tertandingi dimana aplikasi ini memiliki tampilan yang mudah dimengerti sehingga mempermudah pengguna dalam memulai, bergabung, dan 
berkolaborasi dalam pertemuan online melalui perangkat apa saja. Zoom memiliki pengaturan keamanan yang handal untuk memastikan rapat yang bebas gangguan, sehingga aplikasi ini sangat direkomendasikan untuk membantu guru dalam menciptakan suasana belajar yang berbeda dan tidak terbataskan oleh ruang.

Sedangkan Webex adalah sebuah aplikasi daring yang membuat para penggunanya saling berinteraksi melalui visual, audio dari manapun secara lebih praktis dan mudah [23]. Webex membantu pengguna untuk bekerja jarak jauh secara aman, dimana aplikasi ini terintegrasi dengan baik aplikasi populer lainnya seperti Microsoft Outlook, Google Drive, Microsoft Office 365, dan lain sebagainya. Secara umum, Webex memiliki fitur-fitur yang mirip dengan Zoom Meeting.

Aplikasi-aplikasi dengan teknologi tatap muka di atas umumnya dimanfaatkan oleh guru atau dosen untuk memberikan materi pelajaran dengan metode ceramah. Guru bisa mempresentasikan materi melalui aplikasi Microsoft Powerpoint sekaligus melihat keaktifan peserta didik melalui tanya jawab dan diskusi. Karena berbasis tatap muka, guru dan peserta didik bisa saling mengekspresikan diri dalam proses belajar sehingga kegiatan menjadi lebih hidup.

\section{2) Non-Tatap Muka}

Teknologi berbasis umpan balik langsung dalam bentuk non-tatap muka adalah teknologi yang hanya berorientasi menampilkan teks atau audio untuk berinteraksi secara realtime. Penyaji yang menyampaikan materi dalam bentuk teks atau audio akan direspon balik oleh peserta didik dalam bentuk yang sama. Dengan teknologi non-tatap muka, ekspresi dari penyaji dan peserta didik saat berinteraksi tidak dapat terlihat, namun mereka tetap bisa mengetahui kondisi orang lain dari status online atau tidak yang otomatis terpampang pada profil pengguna. Status online artinya pengguna sedang membuka aplikasi dan terhubung ke jaringan internet [24].

Contoh dari teknologi non-tatap muka adalah aplikasi-aplikasi instant messaging, seperti aplikasi Whatsapp dan Telegram. Whatsapp sebuah aplikasi yang bertujuan untuk mengirim dan menerima pesan secara gratis [25]. Aplikasi ini juga memungkinkan penggunanya untuk membentuk group yang terdiri dari beberapa orang, sehingga lebih mempermudah dalam menginformasikan sesuatu. Pengguna Whatsapp juga bisa mengirimkan berbagai jenis dokumen, seperti dokumen PDF, dengan ukuran maksimal 100MB [26].

Sementara itu, Telegram adalah aplikasi untuk saling berkirim pesan yang bisa berjalan pada platform mobile dan desktop dengan fokus pada keamanan dan kecepatan [27]. Memiliki desain tampilan yang mirip dengan Whatsapp, aplikasi Telegram juga mempunyai fitur-fitur yang ada pada kompetitornya tersebut. Salah satu poin perbedaannya adalah aplikasi Telegram menyimpan seluruh percakapan dalam cloud server sehingga data percakapan bisa dibuka kapan saja. Fitur ini berbeda dengan Whatsapp yang mewajibkan pengguna untuk membuat cadangan (back-up) data percakapan ke Google Drive masing-masing, sehingga jika berganti perangkat mobile dan tidak melakukan pencadangan data, maka pengguna akan kehilangan seluruh riwayat percakapannya.

Perlu diperhatikan bahwa pada aplikasi Whatsapp maupun Telegram terdapat fitur audio dan video call, namun fitur tersebut tidak lantas membuat aplikasi ini tergolong teknologi tatap muka. Karena fitur tersebut hanya diperuntukan untuk percakapan antar 2 orang pembicara, sehingga tidak dapat berbagi informasi dengan jumlah peserta yang banyak. Selain itu, fitur tersebut tidak menawarkan share screen sehingga penyaji tidak bisa menunjukkan materi presentasinya.

Salah satu contoh kegiatan yang memanfaatkan teknologi non-tatap muka adalah kegiatan bimbingan tugas mahasiswa. Pada waktu yang telah disepakati, dosen dan para mahasiswa dapat berinteraksi melalui pesan text yang dikirimkan dan mengirimkan hasil review ataupun perbaikan tugas melalui group Whatsapp atau Telegram yang dapat ditanggapi langsung oleh siswanya.

\section{b) Berbasis Umpan Balik Tidak Langsung}

Teknologi berbasis umpan balik tidak langsung merupakan jenis teknologi yang memungkinkan pemateri untuk membagikan materi pembelajaran tanpa mengetahui kondisi peserta didik sehingga pemateri tidak mendapatkan umpan balik (tanggapan) secara langsung pada saat itu. Sebagai contoh, di tengah penyampaian materi, penyaji ingin bertanya mengenai sejauh mana pemahaman peserta, tentu saja pemateri tidak langsung mendapatkan respon, karena respon baru dapat diberikan setelah materi tersebut dipublikasikan. Pada teknologi berbasis umpan balik tidak langsung, pembuatan dan penayangan materi dilakukan pada waktu yang berbeda sehingga peserta didik tidak bisa menyela atau mengganggu penyaji saat proses penyampaian materi. 
Berdasarkan karakteristik konten atau jenis materi, teknologi berbasis umpan balik tidak langsung dapat digolongkan menjadi 3 jenis, yaitu teknologi dengan konten audio, konten audio visual, dan konten teks.

1) Konten Audio

Teknologi berbasis umpan balik tidak langsung dengan konten audio memiliki karakteristik yaitu materi atau bahan ajar yang disampaikan hanya berupa suara pengajar saja. Peserta didik tidak bisa melihat garis-garis besar topik pembahasan atau animasi materi sehingga peserta hanya bisa meresapi dan membayangkan materi yang diberikan. Walaupun demikian, aplikasi dengan konten audio ini cocok diberikan kepada peserta didik yang sudah berusia dewasa, dimana mereka telah mahir atau menguasai materi namun hanya perlu mengulang atau memperdalam lagi materi yang sudah pernah dipelajari.

Contoh aplikasi populer dengan konten audio adalah aplikasi Apple Podcast dan Castbox. Aplikasi ini mirip seperti siaran radio secara digital yang bisa didengarkan melalui smartphone [28]. Pengguna bisa memilih materi apa yang akan didengarkan sekaligus bisa memberikan nilai atau rating terhadap materi tersebut [29].

2) Konten Audio Visual (Multimedia)

Konten audio visual merupakan sebuah konten yang dinilai paling baik, karena meliputi audio (mendengar) dipadukan dengan visual (melihat). Audio visual dapat digunakan sebagai media penunjang dalam kegiatan pembelajaran, karena informatif, efektif, dan dapat meningkatkan kreativitas diri peserta didik. Dengan menggunakan audio visual guru dapat memberikan nuansa pembelajaran lebih menyenangkan serta dapat menjadikan suatu konsep teoritis menjadi lebih realistis karena efek visualisasi yang dimilikinya. Konten lain yang memiliki kemampuan menyerupai audio visual adalah konten multimedia. Pembelajaran dengan konten multimedia merupakan teknologi yang menggabungkan teks, suara, gambar, animasi, dan video menjadi satu kesatuan media interaktif yang utuh sehingga bisa dinikmati oleh peserta didik [30].

Meskipun memiliki keunggulan berupa konten yang menarik dan interaktif, menggunakan teknologi ini membuat peserta sulit untuk berpindah-pindah ke sub materi yang diinginkan dalam 1 video materi. Alasannya, peserta didik tidak mengetahui pada menit keberapa sub topik yang diinginkan tersebut berada. Dengan demikian, bagi peserta didik dewasa yang ingin mempelajari ulang materi yang sudah pernah dikuasainya, teknologi audio visual atau multimedia tidak cocok karena mereka tidak bisa melakukan pembelajaran cepat atau skimming.

Salah satu contoh yang termasuk konten audio visual yaitu youtube. Aplikasi Youtube sebuah situs web berbagi video yang memungkinkan penggunanya untuk mengunggah, menonton, dan membagikan apa yang diunggah [31]. Bagi para pengguna youtube yang tidak memiliki akun atau tidak terdaftar tetap dapat menonton video, sementara untuk dapat mengunggah video pengguna wajib mendaftar dan membuat sebuah channel atau saluran. Video-video yang telah diunggah bisa dikomentari dan disukai oleh penonton sehingga pemilik video bisa mengetahui bagaimana respon dari para pengguna. Penonton juga bisa menekan tombol berlangganan pada channel tertentu sehingga ketika ada video baru yang dipublikasikan pada channel tersebut, penonton akan mendapatkan pemberitahuan.

\section{3) Konten Teks}

Teknologi berbasis umpan balik tidak langsung dengan konten teks memiliki karakteristik utama yaitu materi atau bahan ajar yang disampaikan sebagian besar berupa tulisan cetak. Untuk memperkaya isi bahasan, teknologi ini memungkinkan pengajar untuk menyisipkan konten-konten multimedia di sela-sela paragraf, seperti konten grafik, gambar, animasi, maupun video. Teknologi jenis ini mirip seperti buku sebagai sarana pembelajaran, dimana peserta dapat mencari topik paragraf tertentu dengan cepat. Peserta tidak harus runut membaca materi dari awal sampai akhir, tetapi bisa langsung berpindah-pindah ke sub pokok bahasan atau paragraf yang diinginkan. Untuk dapat berinteraksi dengan pengajar, peserta didik bisa memanfaatkan fitur komentar yang terdapat pada setiap artikel untuk menulis pertanyaan atau tanggapan terhadap materi yang disajikan. Salah satu contoh konten berbasis teks adalah blog.

Blog memfokuskan layanan untuk menulis dalam bentuk daring [32]. Ciri utama dari blog adalah terdapat identitas yang terdiri dari nama dan alamat yang dapat diakses secara daring, isi yang berupa informasi, dan artikel [33]. Blog ini dapat digunakan oleh kalangan remaja ataupun dewasa untuk latihan menulis dan berbagi informasi. Beberapa contoh layanan blog populer dan gratis untuk 
digunakan adalah Wordpress yang bisa diakses pada laman https://wordpress.org dan Blogger yang bisa diakses pada laman https://www.blogger.com/.

\section{B. Teknologi Evaluasi}

Teknologi evaluasi adalah teknologi yang memungkinkan penyaji untuk memberikan soal-soal evaluasi yang dilengkapi dengan kunci jawaban, sehingga sistem dapat secara otomatis menilai jawaban peserta didik. Untuk dapat dinilai secara otomatis, model-model soal yang diberikan umumnya terbatas seperti soal pilihan ganda. Jika soal yang diujikan memiliki jawaban yang kompleks, seperti soal esai, maka sistem tetap membutuhkan peran pengguna (penyaji) untuk menilai benar-salah dari jawaban yang dimasukkan oleh peserta didik. Hasil evaluasi berupa nilai akumulatif, baik yang dinilai otomatis oleh sistem maupun dinilai manual oleh penyaji, disimpan pada database sehingga penyaji bisa melihat ranking nilai seluruh peserta. Menariknya, penyaji bisa menganalisa ujian yang sudah diberikan, misalnya mencari soal-soal mana yang memiliki tingkat kesalahan tertinggi, berapa rata-rata waktu pengerjaan tiap-tiap soal, dan lain sebagainya.

Salah satu contoh aplikasi sederhana untuk teknologi evaluasi ini adalah Quizizz yang bisa diakses melalui browser pada halaman https://quizizz.com, atau diunduh pada Google Play Store dan App Store. Aplikasi ini memiliki desain antarmuka yang menarik dan mudah dipahami.

\section{Platform Khusus}

Berbeda dengan karakteristik teknologi sebelumnya dimana teknologi-teknologi tersebut sesungguhnya tidak didesain untuk keperluan pengajaran, teknologi platform khusus umumnya dibangun secara eksklusif untuk memenuhi kebutuhan pendidikan jarak jauh secara optimal. Pengembang telah menganalisa fitur-fitur apa saja yang dibutuhkan pada pembelajaran dalam jaringan sehingga sistem yang dikembangkan memiliki kemampuan lengkap dalam sebuah platform terintegrasi. Dapat dikatakan bahwa teknologi platform khusus merupakan perpaduan antara teknologi pemberian materi dan teknologi evaluasi. Artinya, dalam 1 sistem ini, terdapat menu untuk mengunggah silabus dan materi, dan menu untuk melakukan evaluasi dalam bentuk soal-soal latihan atau lembar penugasan. Ditambah dengan dukungan dari tim administrator yang handal, teknologi jenis ini merupakan teknologi terbaik untuk melakukan manajemen kegiatan belajar mengajar secara online. Namun, karena dirancang khusus, dibutuhkan dana pengelolaan atau biaya berlangganan yang cukup besar untuk memanfaatkan teknologi jenis ini sehingga hanya beberapa institusi pendidikan yang menggunakannya.

Contoh teknologi dengan platform khusus adalah aplikasi Ruang Guru dan Moodle. Aplikasi Ruang Guru bisa diakses melalui website https://bimbel.ruangguru.com atau diunduh pada Google Play atau App Store melalui smartphone masing-masing. Aplikasi ini menyediakan tata kelola pembelajaran maya sehingga mempermudah peserta didik dalam mempelajari materi dan latihan soal [34]. Untuk bisa menggunakan aplikasi ini, peserta wajib membeli salah satu paket berlangganan tahunan. Sedangkan aplikasi Moodle (bisa diakses pada laman https://moodle.com/) merupakan aplikasi yang sejenis dengan Ruang Guru, namun aplikasi ini memberikan lebih banyak fitur untuk melakukan kustomisasi dan konfigurasi sistem pengajaran. Untuk bisa melakukan hal tersebut, dibutuhkan pengetahuan teknis dasar terhadap pengelolaan sistem informasi.

\section{Hasil Perbandingan dan Analisa}

Berdasarkan pembahasan dari masing-masing kategori pada teknologi pembelajaran dalam jaringan, maka dapat dirangkum perbandingan keunggulan dan kelemahan sebagai berikut.

Tabel 1. Analisa perbandingan

\begin{tabular}{|c|c|c|c|}
\hline No & Kategori & Keunggulan & Kelemahan \\
\hline 1 & $\begin{array}{l}\text { Pemberian Materi dengan } \\
\text { Umpan Balik Langsung }\end{array}$ & $\begin{array}{l}\text { Penyaji bisa mengetahui } \\
\text { kondisi terkini peserta didik } \\
\text { dan peserta bisa langsung } \\
\text { menyela materi }\end{array}$ & $\begin{array}{l}\text { Membutuhkan kesepakatan } \\
\text { waktu yang sama agar penyaji } \\
\text { dan peserta bisa sama-sama } \\
\text { online }\end{array}$ \\
\hline 1.1 & $\begin{array}{l}\text { Mekanisme Tatap Muka } \\
\text { Online }\end{array}$ & $\begin{array}{l}\text { Penyaji bisa melihat peserta } \\
\text { yang benar-benar menyimak }\end{array}$ & Boros bandwidth \\
\hline 1.2 & $\begin{array}{l}\text { Mekanisme Non-Tatap } \\
\text { Muka }\end{array}$ & Lebih hemat bandwidth & $\begin{array}{l}\text { Penyaji hanya bisa mengetahui } \\
\text { apakah materi sudah diterima }\end{array}$ \\
\hline
\end{tabular}




\begin{tabular}{|c|c|c|c|}
\hline & & & dan sudah dibaca. \\
\hline 2 & $\begin{array}{l}\text { Pemberian Materi dengan } \\
\text { Umpan Balik Tidak } \\
\text { Langsung }\end{array}$ & $\begin{array}{l}\text { Penyaji bisa mengirimkan } \\
\text { materi kapan saja }\end{array}$ & $\begin{array}{l}\text { Penyaji tidak mengetahui siapa } \\
\text { saja yang sudah membaca } \\
\text { materi dan peserta } \\
\text { membutuhkan waktu tunggu } \\
\text { yang lebih lama untuk menerima } \\
\text { jawaban atas pertanyaan yang } \\
\text { diajukan. }\end{array}$ \\
\hline 2.1 & Audio & $\begin{array}{l}\text { Hemat bandwidth, cocok untuk } \\
\text { peserta dewasa yang sudah } \\
\text { pernah mendapatkan materi }\end{array}$ & $\begin{array}{l}\text { Peserta harus bisa } \\
\text { membayangkan materi yang } \\
\text { disampaikan dan peserta sulit } \\
\text { melakukan pencarian cepat sub } \\
\text { topik yang diinginkan }\end{array}$ \\
\hline 2.2 & Audio Visual & $\begin{array}{l}\text { Sangat interaktif, peserta bisa } \\
\text { mendapatkan gambaran utuh }\end{array}$ & $\begin{array}{l}\text { Boros bandwidth dan peserta } \\
\text { sulit melakukan pencarian cepat } \\
\text { sub topik yang diinginkan }\end{array}$ \\
\hline 2.3 & Teks & $\begin{array}{l}\text { Bisa melakukan pindai cepat } \\
\text { sebuah materi }\end{array}$ & $\begin{array}{l}\text { Karena konten utama berupa } \\
\text { teks, peserta mudah bosan }\end{array}$ \\
\hline 3 & Teknologi Evaluasi & $\begin{array}{l}\text { Soal-soal ujian bisa teracak } \\
\text { dan penilaian bisa lebih cepat } \\
\text { dan mudah }\end{array}$ & $\begin{array}{l}\text { Sulit melakukan pengawasan } \\
\text { peserta didik dalam menjawab } \\
\text { soal secara jujur }\end{array}$ \\
\hline 4 & $\begin{array}{l}\text { Teknologi Platform } \\
\text { Khusus }\end{array}$ & Fitur-fitur sangat lengkap & $\begin{array}{l}\text { Biaya berlangganan atau } \\
\text { pengelolaannya cukup besar }\end{array}$ \\
\hline
\end{tabular}

Secara umum, teknologi pembelajaran dalam jaringan merupakan solusi yang baik untuk memenuhi kebutuhan pengajaran di era milenial yang mengusung konsep Merdeka Belajar. Namun, jika dibandingkan dengan metode pengajaran tatap muka langsung, teknologi ini masih memiliki banyak kelemahan sehingga belum bisa menggantikan pembelajaran konvensional sepenuhnya. Berikut akan diuraikan hasil analisa kekurangan teknologi pembejalaran dalam jaringan.

1. Siswa dan guru tidak bisa melihat gestur tubuh

Dengan teknologi pembelajaran dalam jaringan gestur tubuh guru dalam menyampaikan materi tidak dapat terlihat, sehingga mengurangi daya tarik

2. Mood hilang karena jaringan bermasalah

Kegiatan belajar dengan memanfaatkan teknologi dalam jaringan sangat bergantung pada jaringan sehingga apabila jaringan mengalami masalah maka kegiatan belajar menjadi terhambat dan dapat mempengaruhi minat belajar menurun

3. Tidak bisa mendapatkan penguatan/motivasi

Dalam kegiatan belajar penguatan sangat penting untuk membantu siswa dalam mencapai target belajar, tetapi jika kegiatan belajar dilakukan dengan teknologi jaringan penguatan tersebut tidak dapat tersampaikan secara maksimal ke siswanya.

4. Kegiatan terbatas

Kegiatan belajar menjadi terbatas dengan teknologi dalam jaringan, karena antara guru dengan siswa berada di tempat yang berbeda dengan situasi yang berbeda pula. Kegiatan yang hanya memungkinkan untuk dilakukan adalah tanya jawab dan diskusi, sedangkan dengan pembelajaran konvensional guru dan siswa dapat bersama-sama mengeksplorasi benda-benda di sekelilingnya secara langsung yang bisa saja ada kaitannya dengan materi.

5. Sulit menilai sikap siswa saat belajar

Dalam kegiatan belajar yang dinilai terdiri dari 3 aspek yaitu kognitif, afektif, dan psikomotorik. Jika kegiatan belajar dengan cara konvensional dapat dengan mudah menilai ketiga aspek tersebut, berbeda halnya dengan menggunakan teknologi dalam jaringan. Belajar dengan teknologi dalam jaringan guru sulit untuk menilai aspek afektif dari siswanya, karena tidak dapat bertemu secara langsung di satu tempat yang sama. Dengan tempat yang berbeda, kemungkinan sikap siswa yang ditunjukan tidak seperti saat belajar secara konvensional di dalam kelas. Siswa bisa saja tidak jujur dengan alasan sinyal dan tidak peduli dengan lingkungan belajarnya. 


\section{SIMPULAN DAN SARAN}

Berdasarkan pembahasan tersebut maka dapat ditarik simpulan bahwa terdapat beberapa jenis teknologi yang dapat digunakan dalam kegiatan belajar dalam hal ini pembelajaran jarak jauh. Teknologi tersebut terdiri dari beberapa jenis sesuai karakteristiknya seperti, tatap muka langsung, dan non tatap muka yang tentunya memiliki kelebihan serta kekurangannya masing-masing.

Beberapa saran bagi penelitian selanjutnya yaitu agar melakukan uji efektivitas dari penggolongan teknologi yang telah dipaparkan.

\section{DAFTAR PUSTAKA}

[1] A. M. Pratama, "Indeks Modal Manusia Indonesia Kalah Jauh dari Singapura dan Vietnam," Kompas.com, 2019. .

[2] A. Hapsari and S. Ritohardoyo, "Analisis Peletakan Genetic Moment Sejarah Matematika Dalam Aktivitas Pembelajaran," J. Chem. Inf. Model., vol. 53, no. 9, pp. 1689-1699, 2013.

[3] L. D. Herliandry, N. Nurhasanah, M. E. Suban, and H. Kuswanto, "Pembelajaran Pada Masa Pandemi Covid-19," JTP - J. Teknol. Pendidik., vol. 22, no. 1, pp. 65-70, 2020, doi: 10.21009/jtp.v22i1.15286.

[4] N. Isradini, L. H. Maula, and A. Sutisnawati, "Peran Teknologi Informasi Dan Komunikasi Pada Pembelajaran Daring Di Masa Pandemi Covid-19," J. Persada, vol. III, no. 3, pp. 176-181, 2020.

[5] I. W. O. Meinarta, L. E. Tripalupi, and K. R. Suwena, "Vol : 4 No : 1 Tahun 2014 Vol : 4 No : 1 Tahun 2014," Stud. Komparat. Prestasi Belajar Mhs. Yang Aktif Dan Tidak Aktif Dalam Organ. Kemahasiswaan Feb Undiksha, vol. 4, no. 1, 2014.

[6] K. Basuki, "Metode Komparatif," ISSN 2502-3632 ISSN 2356-0304 J. Online Int. Nas. Vol. 7 No.1, Januari - Juni 2019 Univ. 17 Agustus 1945 Jakarta, vol. 53, no. 9, pp. 1689-1699, 2019, [Online]. Available: www.journal.uta45jakarta.ac.id.

[7] M. Yaumi, Media dan Teknologi Pembelajaran. Prenada Media, 2018.

[8] B. A. Pribadi, Media \& Teknologi Dalam Pembelajaran. Prenada Media, 2017.

[9] M. K. Naserly, "IMPLEMENTASI ZOOM, GOOGLE CLASSROOM, DAN WHATSAPP GROUP DALAM MENDUKUNG PEMBELAJARAN DARING (ONLINE) PADA MATA KULIAH BAHASA INGGRIS LANJUT (Studi Kasus Pada 2 Kelas Semester 2, Jurusan Administrasi Bisnis, Fakultas Ekonomi dan Bisnis, Universitas Bina Sa," Aksara Public, vol. 4, no. 2, pp. 155-165, 2020.

[10] A. Wilson, "Penerapan Metode Pembelajaran Daring (Online) melalui Aplikasi Berbasis Android saat Pandemi Global," SAP (Susunan Artik. Pendidikan), vol. 5, no. 1, 2020, doi: 10.30998/sap.v5i1.6386.

[11] A. Gozali, "Bimbingan dan konseling berbasis teknologi informasi pada masa PSBB ( Pembatasan Sosial Berskala Besar )," J. Bimbing. Konseling Pendidik. Islam Coution J. Couns. Educ. Layanan, vol. 1, no. 2, pp. 36-49, 2020, [Online]. Available: http://journal.bungabangsacirebon.ac.id/index.php/coution/article/view/117.

[12] M. Salehudin, "Dampak Covid-19: Guru Mengadopsi Media Sosial Sebagai E-Learning Pada Pembelajaran Jarak Jauh," J. MUDARRISUNA Media Kaji. Pendidik. Agama Islam, vol. 10, no. 1, p. 1, 2020, doi: 10.22373/jm.v10i1.6755.

[13] S. Sudarmoyo, "Podcast sebagai Alternatif Media Pembelajaran Jarak Jauh," Edudikara J. Pendidik. dan Pembelajaran, vol. 5, no. 2, pp. 65-73, 2020.

[14] L. A. Abdillah, "Students learning center strategy based on e-learning and blogs," arXiv Prepr. arXiv1307.7202, 2013.

[15] E. Wicaksana, "Efektifitas Pembelajaran Menggunakan Moodle Terhadap Motivasi Dan Minat Bakat Peserta Didik Di Tengah Pandemi Covid -19," EduTeach J. Edukasi dan Teknol. Pembelajaran, vol. 1, no. 2, pp. 117-124, 2020, doi: 10.37859/eduteach.v1i2.1937.

[16] Z. Abidin, A. Hudaya, and D. Anjani, "Efektivitas pembelajaran jarak jauh pada masa pandemi covid-19," Res. Dev. J. Educ., vol. 1, no. 1, pp. 131-146, 2020.

[17] A. RIKA, "PENGARUH MEMBACA SKIMMING BERBASIS E-LEARNING (GOOGLE CLASSROOM) TERHADAP KEMAMPUAN PEMAHAMAN KONSEP PADA MATA PELAJARAN SKI DI MTS NU KOTAAGUNG," UIN Raden Intan Lampung, 2021.

[18] R. E. Putri, "Model Interaksi dalam E-learning," in Seminar Nasional Informatika (SEMNASIF), 2015, vol. 1, no. 1.

[19] T. W. A. Putro, "MANAGEMENT BANDWIDTH INTERNET PADA JARINGAN LOKAL DENGAN ISA SERVER 2004," J. Informatics Eng. Commun., vol. 1, no. 1, pp. 29-38, 2010.

[20] D. S. Pamuji, "Kemampuan Membaca Cepat Dengan Metode Skimming Siswa Kelas XI IPS 
SMA Negeri 3 Merlung Tahun Ajaran 2016/2017," Pena J. Pendidik. Bhs. Dan Sastra, vol. 6, no. 2, 2017.

[21] P. Aria, "Zoom dan 4 Aplikasi Rapat Online Selama Pandemi Covid-19," Katadata.co.id, 2020. .

[22] Zoom, "Video Conferencing, Web Conferencing, Webinars, Screen Sharing - Zoom," 2020.

[23] Webex, "Video Conferencing, Online Meetings, Screen Share | Cisco Webex," 2020. .

[24] T. Sutikno, L. Handayani, D. Stiawan, M. A. Riyadi, I. Much, and I. Subroto, "WhatsApp, Viber and Telegram: Which is the Best for Instant Messaging ?," Int. J. Electr. Comput. Eng., vol. 6, no. 3, pp. 909-914, 2016, doi: 10.11591/ijece.v6i3.10271.

[25] A. Anjani, I. A. Ratnamulyani, and A. A. Kusumadinata, "Penggunaan Media Komunikasi Whatsapp terhadap Efektivitas Kinerja Karyawan,” J. Komun., vol. 4, no. 1, 2018.

[26] Whatsapp, "Features," 2020. .

[27] Telegram, "Telegram: a New Era of Messaging," 2020. .

[28] Apple Inc, "Apple Podcasts," 2020. .

[29] Castbox, "Best free podcast app for Apple iOS and Android / Let words move you," 2020.

[30] M. Rusli, D. Hermawan, N. N. Supuwiningsih, and S. Bali, Multimedia Pembelajaran yang Inovatif: Prinsip Dasar dan Model Pengembangan. Yogyakarta: Penerbit Andi, 2017.

[31] Youtube, "About Youtube," 2020. .

[32] L. A. Kurniawan, "Pembelajaran Keterampilan Menulis dengan Blog: Telaah Pembelajaran Berjarak," Sasindo, vol. 3, no. 1, 2018.

[33] A. Yuliasari, H. Holilulloh, and H. Yanzi, "Peranan Pemanfaatan Blog sebagai Media Pembelajaran dalam Meningkatkan Motivasi Belajar Siswa," 2014.

[34] N. S. Rahmadani and M. Setiawati, "Aplikasi Pendidikan Online 'Ruang Guru' sebagai Peningkatan Minat Belajar Generasi Milenial dalam Menyikapi Perkembangan Revolusi Industri 4.0," Bahastra J. Pendidik. Bhs. dan Sastra Indones., vol. 3, no. 2, pp. 241-246, 2019. 